\title{
Acoustic and other environmental risks: international legal regulation of prevention means
}

\author{
Irina E. Lapshina* \\ National Research University B auman M oscow State Technical U niversity, 105005, M oscow, Russia
}

\begin{abstract}
This paper defines environmental audit, environmental insurance, environmental risk, acoustic risks, and environmental assessment. Also, the paper analyses the regulatory framew ork for the aforementioned governance mechanisms and characterizes the current state of the environmental audit, insurance, and assessment in R ussia and other countries. L egal regulation of acoustic and other environmental risks is analyzed. The form and matter of the environmental audit, insurance, and assessment are characterized. Finally, the paper highlights the problems and prospects of the statutory regulation of these mechanisms in Russia.
\end{abstract}

\section{Introduction}

Due to the spread of pollution across large transcontinental spaces, environmental problems have become global. It is clear that environmental problems cannot be solved within a separate country; intense international collaboration in environmental protection is a must. For successful implementation of the international environmental policy, scientific, technical, and economic cooperation is of great importance. This cooperation must be based on flawless statutory regulations. In current international law, there are many regional and universal agreements. Their norms aim at regulating relations in the environmental sphere. Declaration of the U nited Nations Conference on the Human Environment [1] is an example of a universal agreement. However, most of the legal arrangements aim to detect committed infringements and remove negative consequences instead of preventing infringements and determining the environmental risk of the future actions of potential offenders. This paper aims to analyze current legal means supporting environmental impact assessment, environmental audit, environmental insurance as components of the environmental protection mechanisms.

*Corresponding author: i-Lapshina@ yandex.ru 


\section{International legal regulation of environmental audit, environmental insurance, environmental assessment.}

International legal regulation of environmental audit broke new grounds in 1996 when the ISO 14000 series and the European Union \& E co-M anagement and A udit Scheme (EM AS) were created. These standards regulate periodic environmental audits allowing companies to obtain a respective certificate. A s of 2017, at least 362610 organizations in 181 countries use ISO 14001 [2]. Environmental audit is a systematic documented process of evaluating the environmental aspect of the activity of a company, as well as objectively obtained and evaluated data to data. The audit aims to define whether forms and conditions of economic activity, management system, or information about these objects comply with the statutory requirements of efficiency criteria in the area of environmental protection and safety. The definition explains that improving the efficiency of environmental protection measures and assessing environmental aspects of the company @activity are two of the most important goals of the environmental audit. The functions of the environmental audit are as follows:

- $\quad$ providing protection for the company @staff, local population, and the environment from potentially harmful impact;

- $\quad$ A nalyzing the possibility of environmental emergencies and hazards;

- A ssessing the real impact of the company on the environment.

The aforementioned functions aim to prevent environmental infringements and crimes. In Japan, the USA and EU environmental audit is mandatory. It aims to improve the environmental efficiency of environmental management policies of the companies in these countries. The Policy in the Sphere of E nvironmental Development of the Russian Federation to 2030 approved by the President on A pril 30, 2012, established environmental audit as one of the elements of the mechanism of enforcing state policy in the area of environmental development. The audit is voluntary, however, the planned Federal Law "On the Environmental Audit" lists the situation when the audit is mandatory [3].

Environmental audit is one of the elements of environmental insurance. Environmental insurance is considered as one of the new elements of the mechanism for protecting the environment and preventing negative consequences of the human activity. Generally, environmental insurance covers general liability of legal entities and sole business owners to protect property interests of citizens and organization if environmental damage was done. W orldwide, environmental insurance is a relatively new field. In this field, USA is one of the leading countries having the most comprehensive insurance environmental risk insurance products.

Environmental risk insurance includes different types of insurance for property and general liabilities for environmental pollution and damages. They involve the insurance for liability for environmental pollution by hazardous substances and production waste disposed of in water bodies, soil and atmosphere; insurance for liability for marine oil pollution and negative consequences thereof. B esides, liability insurance may also involve the liability for damage done to third parties due to the peaceful uses of atomic energy. Recently, regulations establishing liability for environmental pollution have been introduced in the international law. Currently, however, there is only one international convention regulating the liability of ship owners for leakage and spillage of oil products and the damage done by them [4]. This convention was approved on N ovember 29,1969 , in B russels. It is currently ratified by most of the countries. A ccording to the norms of the convention, the owner of a ship registered in a Contracting State is required to maintain a guarantee of a bank or a certificate delivered by an international compensation fund to cover his liability for pollution damage up to the limits 
of liability under this Convention. Depending on the ship tonnage, the shipowner can limit his/her liability.

In 1971, the International Compensation Fund was established. The goal of the fund is to compensate for the damages of the damaged party if either the amount of damage is greater than limits established by the norms or the owner is unable to cover the damage himself. According to the Convention, the compensation must cover the costs of cleanup, repair, prevention, and removal of pollution damage.

In EU countries, such as Denmark, Italy, France, N etherlands, insurance pools are created for better regulation and management of environmental risk. The pools enable the extension and stability of the insurance markets. For insurance carriers with little experience in insuring environmental risks, participating in the pool is especially advantageous.

There is no unified definition of the environmental assessment in the international environmental law, and the definition varies across states. According to Article 1 of the Federal L aw "On Ecological Expertise" N o.174-FZ, environmental impact assessment is "is establishing compliance of the documents regulating the economic activity of the subject of ecological expertise to the established technical regulations and law in the area of environmental protection in order to prevent the negative impact of the activity on the environment" [5].

To some extent, the legislation of other countries agrees with the approach of the Russian law. Since the 1970s, many countries start applying the procedure of ecological expertise of projects and environmental impact assessment of social and industrial objects on a regular basis. However, there is no universal approach to the stage of environmental impact assessment in international law. Somewhat universal are the Environmental Impact A ssessment (EIS), and the Environmental A ssessment (EA) developed based on the $N$ ational Environmental Policy Act (USA, 1969). In the 1970s, Canada, A ustralia, and N ew Zealand adopted in US experience. Since the beginning of the 1980s, the environmental assessment procedure had started spreading throughout Europe. On June 3, 1985, the Directive 85/337 (appended by the Directive 97/11 in 1997) of the European Community was passed. The Directive requires national governments to include the procedure of the environmental assessment in the process of decision-making on certain types of projects. Despite the difference between the British, Swedish, and German models of the decision making and planning systems, the countries of the EC started successfully implementing the procedure. At the beginning of 1990s, the environmental assessment had started being increasingly used on the international level. In 1991, 30 countries signed the Convention on Environmental Impact A ssessment in a Transboundary Context at Espo (Finland). The Convention mostly covers energy production on organic fuel whose activity can result in multiple environmental problems. Currently, however, environmental impact is being lessened due to improving the efficiency of energy production, the perfection of exhaust cleaning methods, and reduction of emission of the greenhouse gases, including $\mathrm{CO} 2$ in the atmosphere [6, 7].

International banks play a huge role in the regulation of environmental assessment. For example, the European Bank of Reconstruction and Development (EBRD) conducts an environmental appraisal of all its investment projects and international activity as a part of the general mandatory financial, economic, regulatory, and technical appraisal. Operations of the banks undergo environmental impact assessment and environmental audits.

Having analyzed the international legal regulation of the means of preventing environmental risk, the author should note that environmental audit, insurance, and assessment are not universal tools. They are widely used in the regions where the environmental issues are acute, and states strive to prevent environmental problems. However, these tools are not used in the regions where military, national, religious, or other conflicts take place, or there are no means to maintain environmental security. A Iso, it should 
be noted the making bilateral and multilateral treaties, which will regulate procedures of environmental audit, insurance, and impact assessment, is on the most important tasks today. The treaties shall develop universal norms of international environmental law, which will serve as a reference for most states.

\section{Form and matter of international cooperation in the area of environmental audit, insurance, and impact assessment.}

B ased on the above analysis of the theoretical basis of the mechanisms of environmental audit, insurance, and impact assessment, further attention should be given to their forms, matter, and practical application.

$M$ any countries use the environmental audit as a mandatory mechanism of environment protection and monitoring. It is mostly used by countries with a high level of economic development. M anagement of large companies in countries like the USA, Japan, France identify factors that negatively influence the environment and strive to eliminate the factors. The emergence of the environmental audit is related to the situation in the 1970s. At that time, many economic entities were held accountable for doing damage to the environment, causing additional economic damage. It became evident that mechanisms of preventing environmental damage have to be developed.

A that time, the USA was the leading country in the area of environmental audit. In the USA, strict liability for violating environmental norms by the economic entities was established. There was a need to introduce an environmental audit allowing to assess the activity of companies in the area of environmental protection and establish the level of conformity of the activity to the environmental norms. Such assessments allowed to detect deviation from the norms of the activity of companies or determining the compliance of activities to the recommended norms. It should also be noted that the number of pollutants in the environment, as well as the degree of environmental transformation due to pollution, can be regulated [8]. Thus, the environmental audit becomes a method of stimulating environment protection measures of the enterprises. In the 1990s, the environmental audit had started being used to solve problems of production and consumption waste, ensure the safety of manufactured goods, to combat occupational diseases.

A the end of the 1990s, banks started using the environmental audit to lessen the risks of loan losses related to the drawbacks in the environmental protection activity of companies that borrowed these loans. B esides, many countries (USA, Japan, Jamaica, N orway, France, B el gium, etc.), as well as international financial corporations started using the environmental audit to help enterprises to manage the environmental efforts and lessen financial risks, improvement of environment protection activities, to attract additional capital in the industry and power sectors, and estimate the character and scale of environmental problems in the area of public health. A Ithough the Russian environmental legal framework has progressed recently, it is still not up to the current environmental situation. Legal support of environmental audit has some hurdles. To date, there is no Federal $L$ aw regulating this area. There is a project of the Federal Law "On environmental audit, environmental activity and changes to individual legislations of the Russian Federation," but this law has not been passed. The analysis of the project reveals that most of the norms are devoted to audit organization and legal status of auditors. However, the law does not regulate the audit procedure. Besides, the environmental audit is voluntary, and it is not required for the analysis of projects or existing objects.

Environmental audit is a complex structure including the production audit, the environmental audit of financial activity, and the environmental compliance audit: 
Table. 1 Structure of the environmental audit

\begin{tabular}{|c|c|c|}
\hline Production audit & $\begin{array}{l}\text { Environmental audit of } \\
\text { financial activity }\end{array}$ & $\begin{array}{l}\text { Environmental } \\
\text { compliance audit }\end{array}$ \\
\hline $\begin{array}{l}\text { - Structure, composition, } \\
\text { technical status of } \\
\text { environmental protection } \\
\text { assets; } \\
\text { - Sources of } \\
\text { environmental hazard; }\end{array}$ & $\begin{array}{l}\text { - Current expenses on } \\
\text { environment protection; } \\
\text { - Payments for pollution } \\
\text { within limits; } \\
\text { - Payments for overpollution; } \\
\text { - Payments for natural } \\
\text { resources; } \\
\text { - Capital expenses on } \\
\text { environmental protection; } \\
\text { - Funding of research on } \\
\text { environmental protection } \\
\text { activities; }\end{array}$ & $\begin{array}{l}\text { - Compliance of a project or } \\
\text { activity of an object to the } \\
\text { current regulations; } \\
\text {-compliance with } \\
\text { international principles and } \\
\text { norms; } \\
\text {-compliance with rational } \\
\text { structures of environmental } \\
\text { protection activity; }\end{array}$ \\
\hline
\end{tabular}

As mentioned above, environmental insurance in Russia is fledging. This fact defines some of its features. First, the estimation of environmental damage for cal culating insurance premiums is difficult because the cal cul ations are not comprehensive enough. Environmental damage is determined component-wise, that is, for each component of the environment. Besides, the damage calculations are regulated by multiple unharmonized guidelines and regulations, containing different calculation methods. Second, the regulatory approach to the damage estimation calculation uses fixed quantities, not real damage control expenses. Such estimates give unreliable results in the sense of scale and character of real damage inflicted on the environment. Because of this, there are serious problems of justifying the damage size in formulating the plaintiff $\odot$ claim. In the environment protection area, the Government is often limited to the claims for payment for overpollution of the environment. A rigorous definition of the materiality or significance of the damage inflicted on the environment by a misdemeanor or a crime is directly influenced by an efficient and working method of assessing the environmental impact and calculating the recovery payments. Practically, the governments often do not have the agreements on forming common insurance funds even to cover and amend the loss for the damage inflicted, not to mention the prevention of environmental emergencies.

The $2005 \mathrm{~J}$ ilin disaster serves as a good example of this. Due to the hazard, the Songhua River, which feeds the Amur river, was heavily polluted with benzene. The Chinese government estimated the toxic slick to be more than $80 \mathrm{~km}$; the concentration of heavy metals exceeded the maximum value by more than 100 times. As a result, the waters of the A mur river, supplying the city of K habarovsk, were contaminated. The consequences of the contamination are still in effect. Had the Chinese government localized the slick, the consequences would have been less grave. There was no insurance agreement for such a case, and the Chinese government did not pay for the damages to Russia. A rough estimate of the damage was around half a billion USD.

Foreign and transnational corporations have been stepping up efforts in Russia in recent decades. Situations, similar to the Songhua disaster, are entirely possible in the future. Common approaches to the environmental impact assessment must be formulated. Russian environmental statutory framework must be brought to compliance with international standards so that the amount of damages calculated by Russian regulations is acknowledged by the international jurisdiction. 
Since the 1970s, many states have started conducting environmental evaluations of projects and environmental impact assessment of industrial and social facilities on the environment. A ccording to the Precautionary Principle, all states must evaluate substances, technologies, manufacturing, and other activities that influence or can significantly influence the environment [10]. For example, environmental evaluation is conducted and regulated by the US government according to the regulations of the $\mathrm{N}$ ational Environmental Policy Act, 1969. The mechanism of the environmental evaluation includes

- Evaluation of economic projects to optimize environmental criteria (or approve an alternative project that meets the environmental protection requirements better);

- $\quad$ Evaluation of existing objects for checking the compliance to the environmental standards;

- Environmental evaluation of new products.

Environmental assessment is preferable at the design stage because preventing a disaster is simpler and cheaper than to recover from its possible consequences. On average, the USA conducts the environmental assessment for more than 1000 federal projects per year. The evaluation results in just $2 . . .3 \%$ of projects being suspended or partially stopped. The government controls the environmental parameters of different products, including cosmetics, chemicals, cars, and food products. The Precautionary Principle dictates the need to take individual and collective measures to prevent, lessen, and monitor any environmental pollution. Environmental assessment is the main tool for enforcing these principles. This tool is directly linked to the assessment of the risk of environmental and industrial hazards [11].

A ccording to Russian legislation on environmental assessment, it is conducted according to a common regulation for all industries, resulting in additional work. It means that enterprises with low environmental impact must conduct the impact assessment on the same scale as enterprises with high environmental impact. Such an approach does not save money and resources. Besides, it should be noted that environmental evaluation lacks a strategic stage in Russia, meaning that there is no strategic assessment of the impact of projects on the environment.

\section{Conclusion}

Based on the presented analysis, environmental audit, environmental insurance, and environmental evaluation are important tools of assessment and monitoring in the area of environmental protection in many states. These tools are effects means of verifying the compliance of projects and existing plants and factories to the environmental regulations.

Currently, there is active international collaboration in these areas, manifesting itself in universal and regional treaties, common financial influence tools, the activity of international banks. All these tools play a great role in approving global industrial and construction projects of states in the area, which can potentially inflict great harm to the environment if there is no proper monitoring at the design stages, for example, design of purification works at the international rivers.

However, despite the active evolution of the above mechanisms, there are not enough universal regulations in this area, hampering international environmental cooperation. The issue of bringing national legislation in compliance with international principles, norms, and treaty commitments of certain countries is still relevant. For Russia, the issue of passing the Federal Law "On the environmental audit," improvement of the statutory framework of environmental insurance and environmental eval uation are the most critical issue in the area. Russia must introduce strategic environmental evaluation, create a classifier of enterprises 
based on environmental security, and develop various regulations for evaluating the activity for each category of enterprises in the classifier.

\section{References}

1. Declaration of the United Nations Conference on the Human Environment. URL: https://www.ipcc.ch/apps/njlite/srex/njlite_download.php?id=6471 (20.08.2019)

2. Fundamental set of rules used by organizations worldwide designing and integrating efficient environmental management systems. URL: http://www.iso.org/iso/pressrel ease.htm?refid=R ef 1363 (14.06.2019)

3. The draft Federal law "On environmental audit, environmental auditing and amendments to certain legislative acts of the Russian Federation" (prepared by the Ministry of natural resources) (not introduced in the state Duma of the Federal Assembly of the Russian Federation, the text asat17.12.2014), URL:http://www.consultant.ru/cons/cgi/online.cgi? req $=$ doc $\&$ base $=P R / \& n=126541$ \# 07 411283652719831(22.08.2019)

4. International Convention on liability and compensation for damage in connection with the carriage of dangerous and noxious substances by sea, 1996, as amended by the 2010 Protocol (HNS Convention), URL: https://www.amt-insurance.com/news/amtstrakhovanie-zaklyuchilo-soglashenie-o-sotrudnichestve-s-priznannymklassifikatsionnym-obshchest/ (22.08.2019)

5. Federal Law "On Ecological Expertise" of 23.11.1995 N 174-FX. URL: http://w ww.consultant.ru/document/cons_doc_LA W_8515/ (10.06.2019)

6. V. L osovetskii, V. Lebedev, V. Cherkina, M. IVanchük, Reduction of thermal loading on the environment using heat pumps in the sewage purification works. JEPT, 91, 504 -512 (2018)

7. B. K senofontov, I. Butorova, A. Kozodaev, A. A fonin, R. Taranov, Problems of toxicity of bottom-ash waste. Ecology and Industry of Russia. 21, 4-9 (2017)

8. G. Lavrentieva, O. M irzeabasov, B. Syntsynys, I. Geshel, Radiation risk for surface ecosystem within influence zone of radioactive waste, R R, 27, 65-75 (2018)

9. A. Schvidentko, D. Schepachenko, Climate change and forest fires in Russia, RJ FS, 5, 50-61

10. A. A leksandrov, V. Larionov, S. Suschev. Unified methodology of analyzing risk of natural and industrial emergencies. H BM STU. N S.58, 113-132 